\title{
PENGEMBANGAN INTEGRASI SIDALIH ANTARA PILWALI SURABAYA DAN PILGUB JAWA TIMUR: OPTIMALISASI PELAYANAN PUBLIK KPU KOTA SURABAYA
}

\author{
Agus Machfud Fauzi \\ Program Studi Sosiologi, Jurusan Ilmu Sosial, Fakultas Ilmu Sosial dan Hukum, Universitas Negeri Surabaya \\ Email: agusmfauzi@unesa.ac.id
}

\begin{abstract}
Abstrak
Studi ini bertujuan untuk menyatukan Sistem Informasi Pemilih (SIDALIH) berbasis online antara Pemilihan Walikota Surabaya (PILWALI) dan Pemilihan Gubernur Jawa Timur (PILGUB). Kedua pemerintahan daerah tersebut mempunyai satu program pelayanan kepada para calon pemilih supaya para pemilih terfasilitasi untuk penggunaan hak pilihnya. PILWALI Surabaya yang sementara ini pelaksanaan demokrasi lokal mendahului pemerintah provinsi Jawa Timur yaitu pada tahun 2015, sedangkan pelaksanaan PILGUB Jawa Timur pada tahun 2018. Kedua pelaksanaan pesta demokrasi tersebut mempunyai data pemilih yang berbeda. Pelaksanaan PILWALI Surabaya 2015 mempunyai data pemilih yang masuk dalam Daftar Pemilih Tetap (DPT) lebih besar dibanding dengan data pemilih PILGUB Jawa Timur 2018 pada Daftar Pemilih Tetap (DPT) yang telah mereka tetapkan. Tahun 2018 terjadi tiga tahun setelah 2015, seharusnya DPT pemilihan kepada daerah pada suatu daerah mempunyai data yang lebih banyak karena jumlah penduduk setiap hari ada penambahan, tetapi fakta yang terjadi yaitu ada penurunan jumlah pemilih pada PILGUB Jawa Timur 2018 dibandingkan dengan PILWALI Kota Surabaya 2015. Penulis telah meneliti terhadap perbedaan yang mencolok pada data DPT kedua even Pemilu tersebut, dan bagaimana solusi terhadap kedua Pemilu meski pemerintahan daerahnya berbeda.
\end{abstract}

Kata Kunci: PILGUB; PILWALI; Pemilih; Sidalih; demokrasi lokal

\begin{abstract}
This study aims to unite the Voter Information System (SIDALIH) based online between the Surabaya Mayor Election (PILWALI) and the East Java Governor Election (PILGUB). Both regional governments have a service program for prospective voters so that voters are facilitated for the use of their voting rights. PILWALI Surabaya, which in the meantime the implementation of local democracy preceded the East Java provincial government, namely in 2015, while the implementation of East Java PILGUB in 2018. Both of these democratic parties have different voter data. The implementation of PILWALI Surabaya 2015 has data on voters who are included in the Permanent Voter List (DPT) greater than the 2018 East Java PILGUB voter data on the Permanent Voter List (DPT) they have set. In 2018, there will be three years after 2015, the DPT should have been selected to the regions in a region with more data because there are additional residents every day, but the fact that there is a decrease in the number of voters in PILGUB East Java 2018 compared to PILWALI Kota Surabaya 2015. The author has examined the striking differences in the DPT data of both Election events, and how the solutions to the two elections even though the regional government is different..
\end{abstract}

Keywords: PILGUB; PILWALI; Voter; Sidalih; Local Democracy

\section{PENDAHULUAN}

Pemilihan umum kepala daerah di Indonesia dilaksanakan oleh Komisi Pemilihan Umum (KPU) pada level masing-masing, ada yang dinamai Pemilihan Walikota (PILWALI) oleh KPU Kota, Pemilihan Bupati (PILBUP) oleh KPU Kabupaten dan Pemilihan Gubernur (PILGUB) oleh KPU Provinsi. Esensi dari Pemilihan tersebut adalah memilih para calon kepala daerah dan wakil kepala daerah untuk kepemimpinan dan pembangunan pemerintahan daerah selama lima tahun.
Salah satu program yang dilaksanakan dalam optimalisasi pelayanan publik pada Pemilu kepala daerah yaitu memfasilitasi pemilih dalam penggunaan hak pilih. Mencoblos salah satu pasangan calon hanya diperbolehkan bagi seseorang yang telah terdaftar sebagai pemilih. Agar seseorang masuk dalam daftar pemilih, maka mayarakat yang telah masuk dalam data kependudukan yang telah didata dinas kependudukan dan catatan sipil, selanjutnya akan dimutakhirkan oleh penyelenggara pemilu apakah yang bersangkutan mempunyai hak pilih dan bisa menggunakan hak pilihnya, atau mempunyai hak pilih tetapi tidak diperbolehkan 
menggunakan hak pilihnya karena menjadi TNI/POLRI, atau mempunyai hak pilih tetapi harus berpindah tempat pencoblosannya karena masalah pekerjaan atau kegiatan lainnya

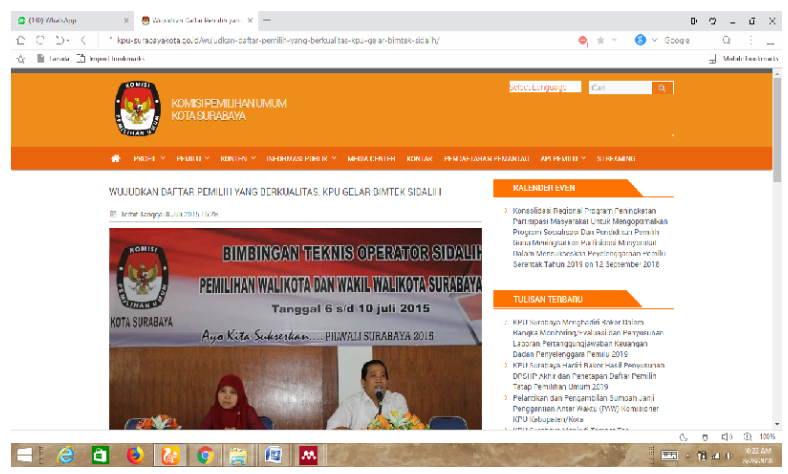

Gambar 1. Website KPU Kota Surabaya tentang Bimtek SIDALIH

Program tersebut secara tersirat telah diatur dalam UU Pemilu No 7 Tahun 2017, meskipun secara teknis KPU telah menerbitkan peraturan KPU dan pedoman teknis lainnya sehingga pemutakhiran pemilih bisa berjalan dengan baik. KPU Kabupaten/Kota dan KPU Provinsi telah melaksanakan instruksi dan petunjuk yang telah dibuat oleh KPU RI dengan bantuan penyelenggara dibawah, ditingkat Panitia Pemiliha Kecamatan (PPK) dan Panitia Pemungutan Suara (PPS).

Efek potensial dari undang-undang Pemilu pada identifikasi pemilih menjadi legitimasi Pemilu. Pesta Demokrasi mendapat legitimasi lebih baik jika pemilih menggunakan hak pilihnya lebih tinggi dari pemilu sebelumnya setelah ada proses pengadministrasian yang dipercaya. Administrasi Pemilu yang kredibel berguna untuk mengantisipasi terhadap beragamnya partai politik dalam bersikap. Pada pelaksanaan pemilu terlihat lebih positif di mana undang-undang yang mengatur administrasi Pemilu mengatur dan berlaku secara baik. Administrasi Pemilu untuk menghindari tuduhan bahwa Pemilu berjalan tidak adil.[ Bowler : 2015: 7]

KPU Kota Surabaya dan KPU Provinsi Jawa Timur memutakhirkan data pemilih untuk mendapatkan data pemilih yang benar, sehingga ketika ditetapkan menjadi Daftar Pemilih Tetap (DPT) maka tidak menjadi sumber permasalahan Pemilu. Para peserta Pemilu kepala daerah menerima dengan senang, masyarakat bisa menggunakan hak pilihnya sehingga menghasilkan pesta demokrasi yang bisa diterima oleh semua pihak.

KPU Kota Surabaya menggunakan Sistem Daftar Pemilih (SIDALIH) untuk pemutakhiran data pemilih. Ini sebuah program berbasis online dengan pekerjaannya dibantu oleh penyelenggara ditingkat bawah, seperti Panitia Pemilihan Kecamatan (PPK), Panitia Pemilihan
Desa (PPS) dan sebagainya. SIDALIH bekerja setelah data penduduk dari Dinas Kependudukan Kota Surabaya (Pemerintah) diserahterimakan kepada KPU Kota Surabaya.

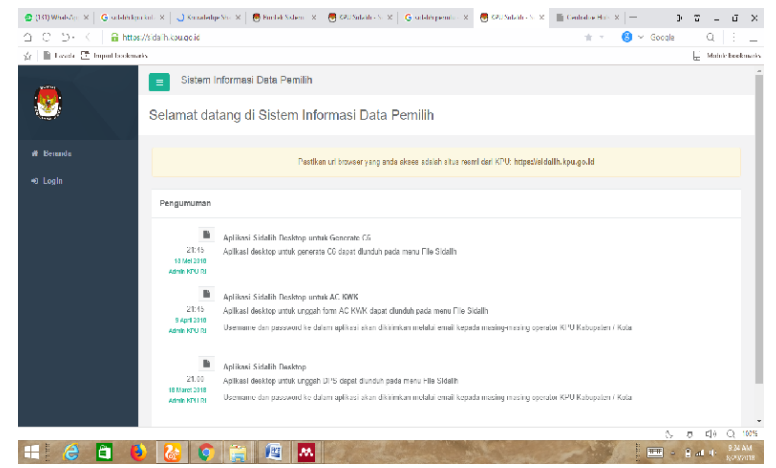

Gambar 2. Website KPU Kota Surabaya tentang SIDALIH

Pertanyaan penelitian yang berdasarkan latar belakang masalah ada dua pertanyaan. Pertama, Bagaimana KPU Kota Surabaya memfasilitasi pemilih dengan SIDALIH? Kedua, Mengapa terjadi perbedaan antara DPT PILWALI 2015 dibandingkan dengan PILGUB 2018? Pertanyaan pertama digunakan untuk mengetahui pelayanan publik oleh KPU Kota Surabaya terhadap warga kota Surabaya yang berkepentingan untuk menghadirkan pemimpin daerah melalui PILWALI Surabaya. Pertanyaan kedua dihadirkan untuk mengetahui apa penyebab terjadi pengurangan pemilih ditahun 2018, idealnya terjadi penambahan pemilih sebab selisih tiga tahun pelaksanaan PILWALI dibandingkan dengan PILGUB.

Metodologi. Peneliti menggunakan metode kualitatif, dengan pendekatan kepada para subjek penelitian dengan pendekatan snaw ball sampling. Peneliti mewawancarai pada informan kunci sebab dengan cara seperti ini bisa menghadirkan jawaban yang lengkap terkait dengan dua pertanyaan yang tertera dalam rumusan masalah.

\section{METODE}

Peneliti menggunakan metode kualitatif, dengan pendekatan kepada para subjek penelitian dengan pendekatan snaw ball sampling. Peneliti mewawancarai pada informan kunci sebab dengan cara seperti ini bisa menghadirkan jawaban yang lengkap terkait dengan dua pertanyaan yang tertera dalam rumusan masalah.

\section{HASIL DAN PEMBAHASAN}

\section{KPU Kota Surabaya Memfasilitasi Pemilih}

Administrasi Pemilu dalam penanganan pemilih tidak pernah selesai sebab pemilih hadir berdasarkan pergerakan penduduk pada suatu daerah, semakin banyak 
kaum urban maka fluktuasi pemilih semakin tinggi. Pada pelaksanaan pemilu ada kreatifitas penyelenggara pemilu agar pengadministrasian pemilih lebih baik, terhindar dari protes dan gugatan. Sistem Daftar Pemilih (SIDALIH) yang ada semenjak pemutakhiran pemilih secara online, merupakan kreatifitas yang positif sehingga pemilih bisa melihat dan mengupdate dirinya sebagai pemilih yang bisa menggunakan hak pilihnya.

Hubungan antara keberhasilan pemilu dan penilaian peserta pemilu terhadap calon parlemen untuk bisa terpilih sangat berhubungan, hal ini sebagaimana pada penelitian yang pernah dilakukan sekitar Pemilu di Inggris. Prediksi penilaian terhadap hasil yang sebenarnya dari pemilihan umum 2010 yaitu kekuatan kemenangan berkorelasi antara penilaian pemilih terhadap calon dengan hasil pemilu terhadap kandidat berkompetisi di daerah pemilihan. Calon mengkalkulasi potensi pemilih yang telah pasti, dia tidak peduli warga masyarakat yang tidak masuk dalam daftar pemilih (Mattes, 2014:186).

Pada sebagian besar negara demokratis, warga sebagai pemilih memiliki kesempatan untuk memberikan suara mereka untuk beberapa jabatan politik, misalkan untuk Pemilu presiden, legislatif, dan perwakilan daerah (Dewan Perwakilan Daerah), legislatif regional (DPRD Provinsi) dan Lokal (DPRD Kabupaten/Kota). Meskipun pemilihan berlangsung tidak pada hari yang sama atau juga pada hari yang sama (Cancela, 2016:268). Sedangkan yang terjadi di Indonesia pada tahun 2019 yaitu pelaksanaannya pemilu dengan lima pilihan (coblosan) bersamaan, hal ini berbeda dengan pemilu tahun sebelumnya yang terjadi perbedaan waktu coblosan antara pemilihan legislatif dengan coblosan presiden.

Ada beberapa agenda yang berhimpitan dengan kegiatan administrasi pemilih, ia berpengaruh terhadap dinamika perpolitikan sekitar Pemilu. Penyelenggara pemilu mempunyai tanggungjawab untuk menjadi pelayan masyarakat untuk menggunakan hak pilihnya, tidak terbatasi oleh satu kegiatan berdiri sendiri, sebab ada banyak kegiatan yang bisa berjalan bersama dengan program dan kegiatan pemilu lain.

Pemerintah daerah memiliki banyak tanggung jawab administrasi dan pemberian layanan publik. KPU Kota Surabaya sebagai bagian dari pelaksanan layanan publik menjadikan pemungutan suara adalah sangat penting. Coblosan merupakan alat yang digunakan warga untuk mengekspresikan preferensi kebijakan. Yang terpilih dari coblosan meruparakan representasi dari warga yang memilihnya. Pada Perkembangannya pemerintah semakin beralih ke Internet sebagai alat untuk menyediakan informasi publik secara online, termasuk informasi yang ditujukan untuk meningkatkan partisipasi warga dalam penggunaan hak pilih, langkah ini terjadi di tingkat nasional dan lokal (King, 2016:3)
Administrasi pemilu dalam fasilitasi pemilih bisa untuk pemetaan bagi calon kontestan. Berbagai ukuran nilai pada masyarakat dan ideologi berkontribusi secara signifikan untuk memprediksi pemilihan presiden, misalkan keyakinan tentang tempat kelahiran Presiden, agama, dan tanggung jawab terhadap ekonomi lemah. Kebencian rasial juga bentuk konservatisme lain yang memiliki efek langsung pada pemungutan suara (Bradberry, 2015:507).

Beberapa penelitian telah melihat signifikansi statistik dari kebencian rasial dalam pemungutan suara, misalkan pada Pemilu Presiden terpilihnya Obama menunjukkan bahwa prasangka adalah faktor pengelompok dalam politik Amerika. Namun efek sikap rasial jauh lebih kecil daripada yang mungkin diharapkan mengingat sejarah ras yang bergolak di Amerika. Sikap rasial terus mempengaruhi politik dan pemungutan suara di era pascaObama, tetapi efeknya cenderung bervariasi, begitu juga isu perempuan (Weisberg, 2015:461)

Hubungan antara pemilihan dan kekerasan, bahwa kekerasan pemilu dapat terjadi sebelum, selama, atau setelah pemilihan. Penyebab kekerasan pemilu berbedabeda tergantung kapan kekerasan terjadi. Kekerasan yang terjadi sebelum pemilihan atau pada hari pemilihan sering merupakan upaya untuk mempengaruhi hasil pemilu dan dengan demikian dapat dikonseptualisasikan sebagai bentuk kecurangan pemilu, sedangkan kekerasan yang terjadi setelah pemilihan mungkin merupakan respons terhadap hasil (Daxecker, 2014:233)

Perilaku memilih berpotensi membelot dari inkumben pada tingkat individu. Kinerja ekonomi yang lemah, diukur dengan menggunakan inflasi, pertumbuhan ekonomi, dan cadangan, memiliki dampak negatif pada kesetiaan elektoral kepada inkumben. Kinerja ekonomi yang buruk menghasilkan ketidakpuasan pemilih dengan inkumben sedangkan kinerja yang baik meningkatkan dukungan bagi partai yang berkuasa, menunjukkan bahwa suara memberikan alat yang efektif untuk akuntabilitas pemilu (Murillo, 2017:8)

KPU Kota Surabaya sebagai penyelenggara Pemilu, harus bersifat netral menghadapi berbagai problematika sekita Pemilu sebagaimana tergambarkan tersebut. Perilaku penyelenggara dalam pengawasan oleh berbagai pihak, baik Badan Pengawas Pemilu (BAWASLU), peserta Pemilu, pemantau pemilu dan masyarakat secara umum yang berposisi sebagai pemilih.

KPU mempunyai tugas yang mulia dalam fasilitasi pemilih pada fungsi sistem pemerintahan demokratis, nilai pekerjaan ini tidak terbatas hanya mengukur benar / salah dalam coblosan, begitu juga tidak cukup hanya terbatasi pemilih telah terdaftar sebagai pemilih (Dusso, 2015:51). Masyarakat urban sebagaimana di Surabaya, mereka cenderung hidupnya berpindah-pindah, tergantung 
pekerjaan dan aktifitas apa yang sedang mereka kerjakan. Pekerjaan dan sesuatu yang menghasilkan uang menjadi prioritas utama dalam memilih tempat hidup mereka, padahal disisi lain mereka mempunyai tugas dan tanggungjawab yang besar terhadap terpilihnya para pemimpin dan para wakil rakyat.

Masyarakat yang berubah menjadi pemilih pada pelaksanaan pemilu, dalam melihat fenomena perpolitikan yang bervariasi, mereka secara tidak sadar telah menjadi pemilih yang menyukai iklan berdasarkan kritik yang membangun. Pada satu sisi, ada upaya aparat keamanan untuk menghalang-halangi kritikan terhadap pemerintah, apalagi ada upaya yang mengarah pada mobilisasi pemilih ke suatu pilihan (O'shaughnessy, 2003:93).

Pengaturan pelaksanaan pemilihan pada tingkat yang berbeda sebagaimana yang terjadi di Jerman, partai Sosial Demokrat mendapat keuntungan dari tingkat pemilih yang lebih tinggi, sedangkan perolehan suara partai Konservatif menurun jika partisipasi pemilu meningkat. Partisipasi pemilih diprogram untuk ditingkatkan dengan menggunakan sosialisasi bagaimana pemilihan secara massif sebagai variabel instrumental (Arnold, 2016:220).

\section{Partisipasi Aktif Pemilih Dengan SIDALIH}

Ada beberapa alasan yang menjadikan masyarakat Surabaya terlibat aktif dalam pelaksanaan PILWALI dan PILGUB Jawa Timur 2018. Yang Pertama adalah SIDALIH menjadikan masyarakat Surabaya terdaftar sebagai pemilih aktif, sehingga mereka bisa menggunakan hak pilih pada hari pelaksanaan pemungutan suara dengan tidak perlu takut tertinggal atau hilang dari DPT karena pemutakhiran pemilih secara online yang dilaksanakan oleh penyelenggara Pemilu.

Kedua, Regulasi yang dibuat KPU sebagai aturan pelaksaan UU Pemilu memudahkan pemilih untuk untuk menggunakan hak pilih. Sebelum pelaksanaan PILGUB Jawa Timur 2018, proses pindah pilih membutuhkan waktu yang cukup panjang, hal ini berbeda dengan persiapan PILGUB Jawa Timur 2018 yang hanya H-1 masih mengurus pindah pilih, hal ini mengakibatkan pemilih punya peluang besar untuk menggunakan hak pilih meski mereka harus berpindah tugas kemana pun tempatnya.

Ketiga, Administrasi kependudukan dengan menggunakan E-KTP sebagai kebijakan baru dari pemerintah, ia sangat membantu proses pemutakhiran pemilih para penyelenggara Pemilu. E-KTP sebagai bahan dasar daftar pemilih yang ada dalam SIDALIH telah mempunyai data pemilih yang realtif lebih bagus sebab sudah tidak ada pemilih yang mempunyai data kependudukan ganda.

Pelayanan KPU Kota Surabaya terhadap pemilih terlihat ada perbedaan antara PILWALI 2015 dengan jumlah pemilih sebanyak 2.280.015 (dua juta dua ratus delapan puluh ribu lima belas), sedangkan DPT PILGUB Jawa Timur 2018 dengan kepastian pemilih sebanyak 2.006.061 (dua juta enam ribu enam puluh satu), selisihnya cukup tinggi sebanyak 273.954 (dua ratus tujuh puluh tiga ribu Sembilan ratus lima puluh empat), yang seharusnya pada PILGUB 2018 lebih banyak jumlah pemilihnya.

Yang menjadi permasalahan adalah antara SIDALIH PILWALI 2015 dan PILGUB 2018 ada perbedaan, meski keduanya sama-sama merupakan produk dari KPU RI. Ada perubahan SIDALIH dengan harapan ada proses perbaikan dalam pemutakhiran hasil pemilih, dan akhirnya DPT lebih valid dan bisa diterima oleh semua pihak, khususnya para peserta Pemilu.

KPU Kota Surabaya sudah berusaha untuk memberikan pelayanan publik secara prima, sebab pemilih diberi layanan pemilih menggunakan SIDALIH, yaitu suatu layanan pemilih dengan basis online, tidak harus pemilih datang ke kantor KPU Kota Surabaya, atau PPK dan PPS. Pemilih dari rumah masing-masing atau dengan gadgetnya mampunya mengecek dan memastikan bahwa dirinya telah masuk dalam Daftar Pemilih Tetap, sehingga hak pilih mereka bisa digunakan untuk kepentingan memeilih calon pemimpin

Jawaban atas Pertanyaan penelitian pada rumusan masalah sebagian sudah terjawab pada pembahasan dan analisis. KPU Kota Surabaya sudah melaksanakan pelayanan publik terkait dengan pemilih dengan menggunakan sistem online berbasis teknologi informasi.

KPU Kota Surabaya memfasilitasi pemilih dengan penggunaan SIDALIH. Sebelum pelaksanaan PILWALI 2015, KPU Kota Surabaya juga telah menggunakan SIDALIH yaitu terakhir pada Pemilu 2014. Program tersebut merupakan bagian yang tidak terpisahkan dari program KPU RI. Perbedaannya antara 2014 dan 2015, maka ada penambahan fasilitas SIDALIH sebab ada perbaikan regulasi untuk memudahkan pemilih menggunakan hak pilih sehingga ada perubahan Sidalih yang lebih baik.

Perbedaan antara DPT PILWALI 2015 dibandingkan dengan PILGUB 2018, karena pengadministrasian penduduk dengan E-KTP lebih terukur, sulit bagi seseorang untuk memiliki E-KTP lebih dari satu meski mempunyai lebih satu tempat tinggal. SIDALIH sebagai instrument pelayanan publik bagi pemilih terus berkembang, karena terjadi perbedaan versi disebabkan perkembangan teknologi maka ada hal yang baru dalam SIDALIH untuk dipahamai dan dijalankan oleh penyelenggara pemilu, di sisi lain hal ini menunjukkan penyelenggara bekerja lebih progresif dan kreatif dalam melayani pemilih. Dengan hadirnya SIDALIH online maka mengurangi buruk sangka masyarakat yang selama 
ini melihat sisi negatif penyelenggara pemilu, begitu juga partai politik peserta pemilu.

\section{PENUTUP}

\section{Simpulan}

Penelitian ini menyimpulkan bahwa antara Sistem Pendaftaran Pemilih Pemilihan Walikota Surabaya pada 2015 dengan Pemilihan Gubernur Jawa Timur 2018, pada dasarnya terjadi kesinambungan data pemilih. Sebab data pemilu sebelumnya merupakan data pembanding dengan data yang datang dari Dinas Kependudukan.

Pemutakhiran pemilih dengan menggunakan sistem berbasis internet, menunjukkan bahwa birokrasi pemerintahan, khusus Komisi Pemilihan Umum Kota Surabaya telah melakukan optimalisasi pelayanan publik terkait dengan kebutuhan para pemilih menjelang pemilu, meski program tersebut tidak terjadi hanya di KPU Kota Surabaya, tetapi juga telah berjalan di KPU kabupaten/Kota, KPU Provisin di daerah lain.

Kekurangan hasil pemutakhiran data pemilih merupakan tantangan bagi penyelenggara pemilu untuk menyempurnakan sistem pelayanan publik berbasis SIDALIH.

\section{Saran}

Saran Penulis adalah penyelenggara pemilu membuat SIDALIH yang berkesinambungan. SIDALIH PILWALI dan PILGUB perlu disambungkan meski dalam tahun yang berbeda, sehingga proses pemutakhiran pemilih terus berjalan tanpa menunggu tahapan even pemilu yang akan datang. Dengan cara ini maka hasil akhir pemutakhiran pemilih secara onlie lebih valid sebab ada proses evaluasi yang berkelanjutan. Sangat tidak baik KPU membuat program layanan publik hanya berlaku sekali atau pada satu even pesta demokrasi.

Regulasi perlu diselaraskan supaya tidak terjadi pengulangan satu pekerjaan pemutakhiran pemilih memulai dari nol setiap persiapan pelaksanaan pemilu. Meski hal ini akan mengurangi pekerjaan teknis lembaga yang seharusnya menyiapkan bahan dasar pembuatan Data Pemilih.

\section{Ucapan Terima Kasih}

Penulis berterimakasih terhadap Pusat Studi Perubahan Sosial dan Media Baru yang telah membantu dalam data dan tempat berdiskusi sehingga bisa untuk memperdalam pembahasan materi Pengembangan integrasi SIDALIH antara PILWALI Surabaya dan PILGUB Jawa Timur.

Penulis juga mengucapkan banyak terimakasih kepada Mas Satrio Purnomo yang merupakan Mantan Komisioner
KPU Kota Surabaya yang sekarang telah pindah tugas menjadi komisioner BAWASLU Provinsi Jawa Timur, dan Mbak Nurul Amalia sebagai salah satu komisioner KPU Kota Surabaya, yang keduanya telah memberikan informasi tentang SIDALIH di KPU Kota Surabaya, selain akses yang mudah website dan informasi online lainnya tentang SIDALIH. Terimakasih kepada Mas Ikhwanudin Alfianto, komisioner Bawaslu Provinsi Jawa timur juga menambah informasi tentang efektifitas SIDALIH sebagai sistem untuk memfasilitasi pemilih dengan mudah mendapatkan hak pilihnya.

\section{DAFTAR PUSTAKA}

Bowler, S \& T. Brunell, T. Donovan, and P. Gronke, "Election administration and perceptions of fair elections,” Elect. Stud., vol. 38, pp. 1-9, 2015.

Mattes, K and C. Milazzo, "Pretty faces, marginal races: Predicting election outcomes using trait assessments of British parliamentary candidates," Elect. Stud., vol. 34, pp. 177-189, 2014.

Cancela, J and B. Geys, "Explaining voter turnout: A meta-analysis of national and subnational elections," Elect. Stud., vol. 42, pp. 264-275, 2016.

King, BA and N. E. Youngblood, "E-government in Alabama: An analysis of county voting and election website content, usability, accessibility, and mobile readiness," Gov. Inf. Q., 2016.

Bradberry, L.A. and G. C. Jacobson, "The Tea Party and the 2012 presidential election," Elect. Stud., vol. 40, pp. 500-508, 2015.

Weisberg, HF, "Racial attitudes effects on voting in 2012: An introduction to the Symposium on the U.S. Presidential Election,” Elect. Stud., vol. 40, pp. 460461, 2015.

Daxecker, UE \& "All quiet on election day? International election observation and incentives for pre-election violence in African elections," Elect. Stud., vol. 34, pp. 232-243, 2014.

Murillo, MV and G. Visconti, "Economic performance and incumbents' support in Latin America," Elect. Stud., vol. 45, pp. 180-190, 2017.

Dusso, A \& "Incorrect voting in the 2012 U.S. presidential election: How partisan and economic cues fail to help low-information voters," Elect. Stud., vol. 37, pp. 50-62, 2015.

O'shaughnessy, N \& “The Limitations of Persuasion?," J. Polit. Mark., vol. 1, no. 1, pp. 117-124, 2003.

Arnold, F and R. Freier, "Only conservatives are voting in the rain: Evidence from German local and state elections," 2016. 